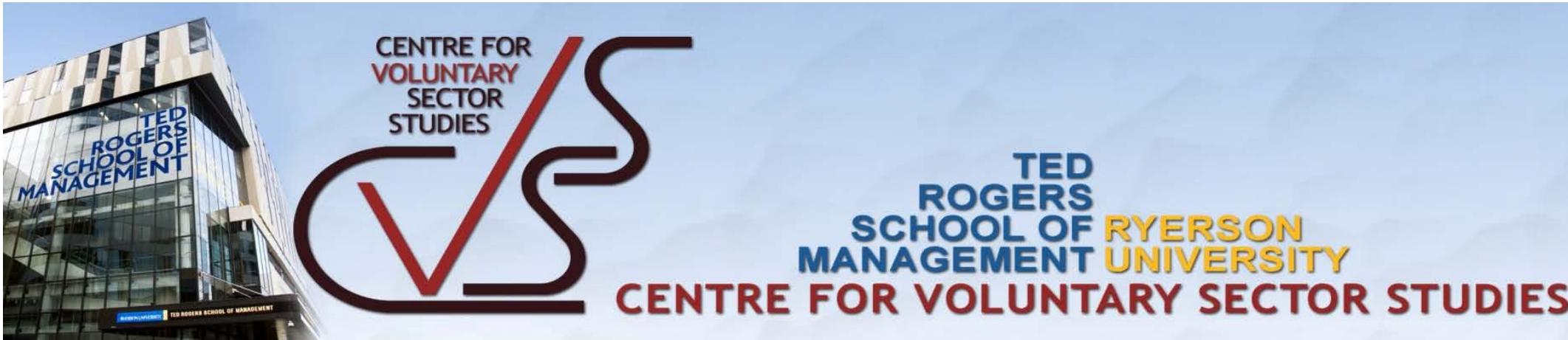

\title{
From Philanthropic Strategy to Strategic Philanthropy: Selected Canadian Case Studies ${ }^{1}$
}

\author{
Mary Foster, Agnes Meinhard, Ida Berger and Pike Wright \\ Centre for Voluntary Sector Studies, Ryerson University
}

Note to the Reader: This paper provides a more in-depth analysis of Working Paper Series Volume 2002(1), as such, there are some redundancies in the two papers.

\section{Working Paper Series}

Volume 2005 (2)

350 Victoria Street

Toronto, Ontario, M5B 2K3

Tel: (416) 979-5000 x 6739 / Fax: (416) 979-5124

cvss@ryerson.ca

http://www.ryerson.ca/cvss/working_papers/

\footnotetext{
${ }^{1}$ We are grateful to the Social Sciences and Humanities Research Council for their support of this research. In addition, we want to thank our Research Assistants Louise Moher and Maame TwumBarima for their content analysis of the interviews.
} 
Using fourteen case studies from Canadian corporations, representing natural resources, finance, retail, technology, food and beverage and communications, this study describes the organizational differences between companies that are truly strategic in their philanthropic practices and those that use social causes to enhance public relations and fulfil marketing objectives.

\section{Introduction ${ }^{1}$}

The rapidly growing literature investigating corporate social responsibility and corporate philanthropy attests to the world-wide interest in this trend, both from an academic perspective and as a legitimate component of commercial success (Burson-Marsteller, 2000; Waddock \& Graves, 1997). As Marx (1999) points out, the evolution of corporate philanthropy from donation programs to strategic philanthropy has been well documented in the nonprofit literature, particularly as it relates to US corporations, and indeed research interest in this topic dates back to the 1930s and 1940s (Carroll, 1999). Smith (1994) suggests that most US corporations established philanthropic foundations in the 1960s to demonstrate their obligation to support the American version of the social contract. Part of that contract involved the separation of profit, nonprofit and government roles.

Canada has a very different history in that voluntary organizations became allies of the state, extending specialized services that the government was uninterested in or unable to provide (Tucker, Singh, \& Meinhard, 1990). Until very recently, the Canadian government has been the primary architect, builder and funder of the social safety net, thereby pre-empting the need for widespread corporate participation in the provision of social services. Thus, the body of knowledge about corporate social responsibility and corporate philanthropy in Canada is more modest and has mostly focused on investigating the impact of social disclosure from an accounting perspective (Levin, 1982; Zeghal \& Ahmed, 1990). Recently, there has been a noticeable shift in policy at all levels of government, even though social expenditures remain the largest single expenditure category in the Canadian federal budget (Prince, 1999). Both the range of services and the amount of funding directed to nonprofit service providers have been severely reduced (Hall \& Banting, 2000). As a result, voluntary organizations have been diversifying their funding sources, and have intensified their search for corporate support (Foster \& Meinhard, 2005). At the same time, 'corporate' Canada has recognized the value of relationships with the voluntary sector both from a marketing perspective and in response to shareholder concerns for community involvement and social responsibility (Pinney, 2001; Schmid \& Meinhard, 2000).

Because Canadian corporations have operated in a social, political and economic environment different from their US counterparts, the scope of participation and the level of philanthropic giving has been lower (Azer, 2003). While the Canadian public believes that corporations provide 10 percent of revenues to charitable causes, corporate philanthropy in reality is at a much lower level - in fact closer to $1 \%$ in 2002 (Muttart Foundation, 2002) and more recently, 3\% (NSNVO, 2005). Since 1988, the Imagine campaign has worked to encourage Canadian companies to donate $1 \%$ of pre-tax profits to Canadian charities hoping to bring Canadian corporations closer to their American counterparts (Azer, 2003). Since the inception of the Imagine program corporate giving has almost doubled, increasing from .064\% of pretax profits in 1988 to $1.04 \%$ in 2000 (Imagine Canada, 2002). The purpose of this paper is to use case studies to explore the evolving and diverse approaches to philanthropy among Canadian corporations. 


\section{Review of Literature}

There is an extensive literature on cause-related marketing (CRM) beginning with Varadarajan and Menon's (1988) seminal article in which they define CRM as "the process of formulating and implementing marketing activities that are characterized by an offer from the firm to contribute a specified amount to a designated cause when customers engage in revenue-providing exchanges that satisfy organizational and individual objectives" (pg. 60). Such activities provide a range of benefits to the corporation including increasing sales and/or profits, and enhancing corporate reputation and/or brand image (Varadarajan \& Menon, 1988). Funds for such activities are often part of the marketing budget rather than the corporate donations or philanthropy budget (Smith \& Higgins, 2000). While the corporation clearly benefits from an association with a social cause through increased sales and profits, nonprofits believe that they too benefit. Association with a well-known brand is thought to increase the credibility of the cause and thus generate more awareness (Fiske Gwin, 2000). Most of the research conducted to date on CRM has focused on consumer response to corporations engaged in and brands associated with cause-related marketing programs (Barone, Miyazaki, \& Taylor, 2000; Webb \& Mohr, 1998; Dean, 2003/2004; Yechiam, Barron, Erev, \& Erez, 2003; Drumwright, 1996).

Phillips (2000) lists other forms of corporate philanthropy besides CRM that provide benefits to both the nonprofit organization and the corporation including in-kind giving, corporate employee volunteer programs and venture philanthropy. For example, some corporations are involved in in-kind services to charitable causes as a way to convert surplus inventory into tax deductions. In addition to helping nonprofit organizations, employee volunteer programs can be viewed as a way to attract and retrain employees, and to build skills and experience that would otherwise require expensive training programs (Murphy, 1995). Kosminsky (1997) defines venture philanthropy as providing technical and business expertise to help launch a program for which a nonprofit organization does not have the in-house capacity. This too can serve as a vehicle for corporations to attract and retain employees and give them experience in making untested ideas successful. These activities are beyond cheque writing, but are they strategic?

The discourse on corporate philanthropy distinguishes between philanthropic strategy and strategic philanthropy. For example, Post and Waddock (1995) point out that firms with a philanthropic strategy have formal and organized processes and procedures for donating. These may include structures to oversee corporate philanthropic activities that can range from cheque writing to support for employees who volunteer their time (McAlister \& Ferrell, 2002). On the other hand, the motivations that underlie strategic philanthropy go much further than the usual benevolence demonstrated in philanthropic strategy. With strategic philanthropy, the choices made in corporate giving are designed to be synergistic with the firm's mission, goals and objectives. Hemphill (2004) suggests that strategic philanthropy has a dual purpose: support for charitable causes and benefits for the corporation. Such strategic philanthropy activities are typically managed professionally and regularly evaluated against stated objectives just like other business activities in the organization (Saiia, Carroll, \& Buchholtz, 2003; Smith, 1994).

Porter and Kramer (2002) have another view on this topic. They disagree with the use of the term strategic and argue that what is commonly categorized as strategic philanthropy is more appropriately labelled as public relations or cause-related marketing because the result is increased goodwill, not contribution to the attainment of important social and economic goals. From their perspective in order to maximize the value of philanthropy and be truly strategic, both social and economic goals need to be addressed. Porter and Kramer suggest that corporations create more value when they use their due diligence skill set to select the best grantees. Nonprofit organizations that are more efficient and effective in delivering services achieve higher social impact. Corporations can also signal other funders about the organizations to support by leveraging their own reputations to provide credibility for these organizations. 
Corporations are also in the position to improve the performance of grant recipients by using their inhouse expertise to build capacity within the nonprofit organization and provide other forms of nonmonetary assistance. Finally, Porter and Kramer believe that corporations have the means to help nonprofits advance knowledge by identifying new and better ways to address social problems. Likewise, they suggest that existing networks of corporations can be leveraged to disseminate this new learning and facilitate global knowledge transfer. Thus, from the perspective of Porter and Kramer, very few firms are actually engaging in strategic philanthropy as they define it.

Both Austin (2000) and Zadek (2004) take the discussion further by presenting a continuum approach to conceptualizing the movement from philanthropic strategy to strategic philanthropy. Austin (2000) views corporate philanthropy within a framework of collaboration. The beginning of this collaboration continuum, philanthropy, is characterized as a basic relationship between a charitable donor and a recipient. The middle type of collaboration, transactional, involves resource exchanges, as illustrated in activities, such as cause-related marketing, event sponsorships and contracts for service. The final end of the continuum represents an integrative stage, in which there is synergy between the corporation's and the nonprofit organization's mission, vision and values that results in collective action and organizational integration. Austin points out that the nature and strength of the relationship between the corporation and the nonprofit organization shifts and changes as one moves along the continuum. Although presenting this as a continuum suggests that there may be a progression from one end to the other, Austin points out that this is not necessarily the case. Likewise, identifying stages implies that there are discrete types of relationships, but Austin cautions that more often than not corporations are hybrids, displaying characteristics of more than one stage at the same time.

Zadek (2004) links growth in attention to corporate social responsibility to larger changes in organizational learning. The learning curve he describes involves five stages: a) defensive, the organization denies its responsibility for societal shortcomings, and only acts to defend reputational attacks; b) compliance, the company sees CSR activities only in the context of protecting its reputation, reducing the risk of litigation and the cost of doing business; c) managerial, responsible business practices become embedded into core management processes; d) strategic, being socially responsible is viewed as a competitive advantage and is integrated into core business strategies; and e) civil, the organization becomes an advocate for CSR in the broader marketplace.

While both of these models use different terms, in fact, they appear to be describing the same process and progression of organizational learning and change. At one end, Zadek's defensive stage is very similar to Austin's philanthropic stage. Likewise, at the other end of the continuum, Austin's integrative stage is similar to Zadek's civil stage. Austin terms the middle stage as transactional, whereas Zadek differentiates among three transitional types: compliance, managerial and strategic. Both authors illustrate the application of their frameworks by showing the progression of one corporation along the continuum and through the stages. Austin (2000) uses Timberland's relationship with City Year to chronicle and analyse the shifts that occurred in commitment, resource allocation and value placed on corporate philanthropic activities as Timberland progressed along his proposed collaboration continuum. Austin (2000) demonstrates progress along his collaboration continuum by analyzing the shifts in commitment, resource allocation and value placed on philanthropic activities that occurred over the span of Timberland's relationship with City Year. Zadek (2004) uses the history of Nike to illustrate the tension between corporate performance and societal expectations of responsibility as Nike learned more about how to meet these expectations by engaging in and embracing the values of CSR. 


\section{Research Focus}

The objectives of this paper are:

1. To explore the usefulness of Austin's (2002) and Zadek's (2004) frameworks for understanding the range of philanthropic practices among Canadian corporations.

2. To gain a deeper understanding of the factors that differentiate corporations that are involved in attaining both social and economic goals, what Porter and Kramer (2002) term true strategic philanthropy, and the rest.

\section{Method}

\section{Design}

In 2004, we conducted 14 one hour in-depth interviews with the manager or executive in charge of corporate philanthropy at Ontario-based corporations. These corporations represented financial services, food and beverage, media, technology, retail and natural resources. We held these interviews in the office of the interviewee and we used a semi-structured interview schedule to guide the conversation. The interviews were audio-taped and transcribed verbatim. Because two interviewers were present for most interviews, back-up notes were available to assist with interview segments that were difficult to hear.

\section{Sample}

In 2002 we conducted a study of 119 Canadian-based firms chosen from the SEDAR (System for Electronic Document Analysis and Retrieval) dataset to determine the emphasis placed on corporate social responsibility activities in Annual Reports and corporate Websites. As Chart 1 illustrates, we found that companies in the natural resources and finance sectors gave the highest exposure to CSR activities in their public relations materials whereas technology companies gave the lowest (Foster \& Meinhard, 2002). For this follow-up study we chose companies from our original 119 company database as follows: natural resources (2); retail (2), technology (3), communications (2), food and beverage (2), finance and insurance (3).

\section{Analysis}

The overall purpose of these interviews was to understand the company's perspective on its perceived role and the role of the government and the nonprofit sector in contributing to civil society and the policies and procedures in place to support its approach. Two trained research assistants and one of the co-authors independently content analysed the interview transcripts to identify the key themes and issues related to corporate social responsibility and philanthropy and then reached consensus on their findings. 


\section{Chart 1: Prominence by Industry Code}

( $n=119$ companies)
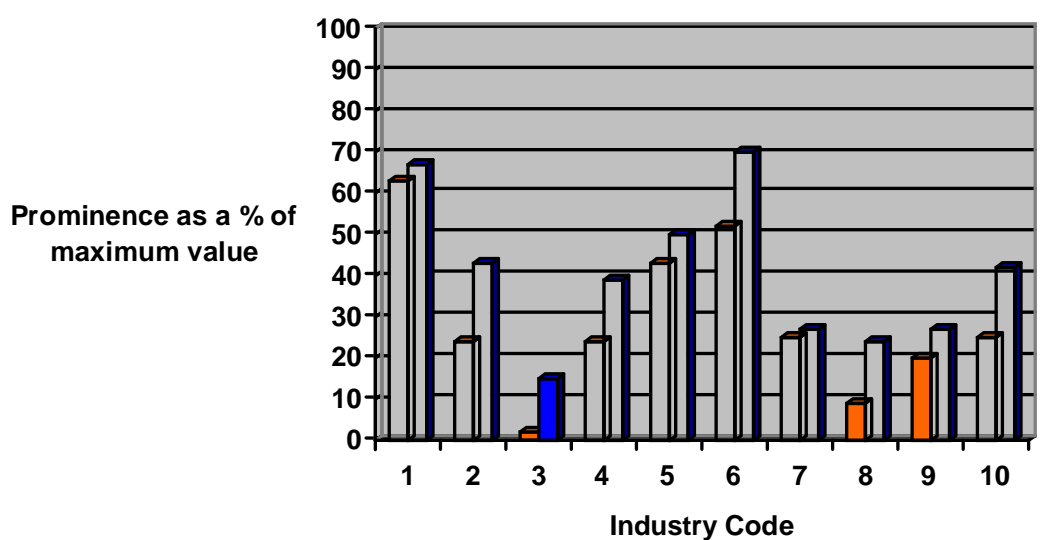

口Annual Report Prominence

Website Prominence

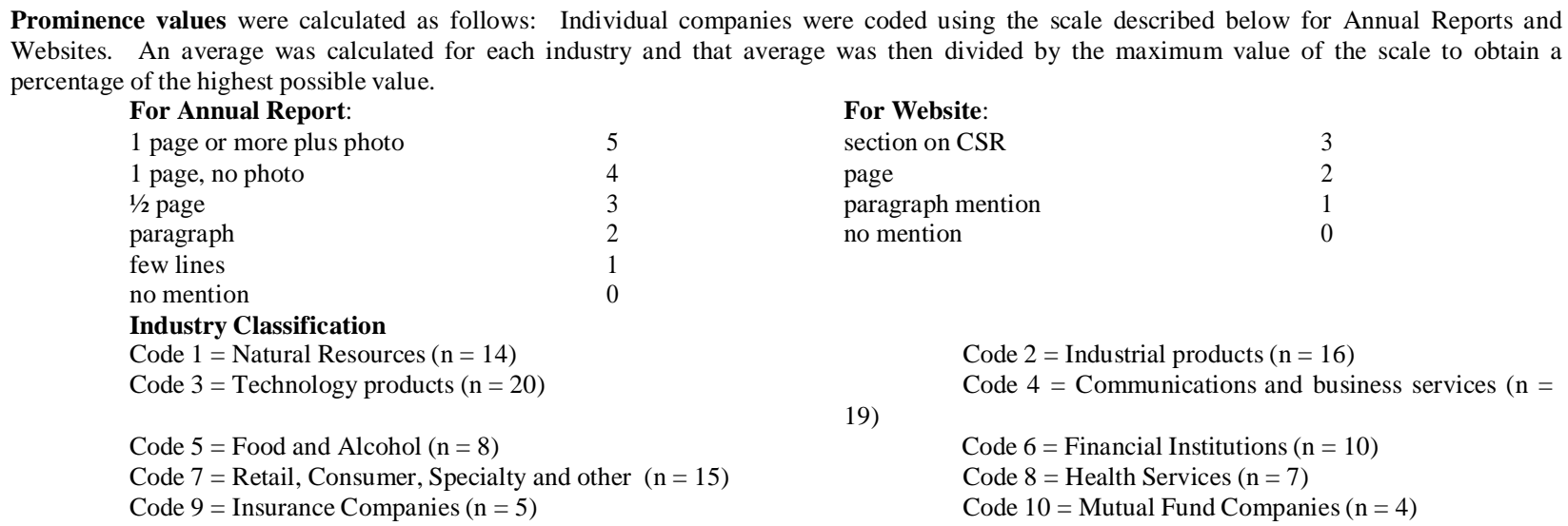

(Source: Foster \& Meinhard, 2002)

\section{Background Information on Corporations Interviewed}

In order to protect the confidentiality of our interviewees, corporations are identified by number and sector only. Table 1 describes some of the key characteristics of each participating corporation. All of the corporations in the sample are public companies. Eight of the fourteen are global companies, with four having a national focus and one a regional. Four are subsidiaries of Canadian companies, and two of US companies. The business focus of four is primarily business to consumer; that is marketing products or services to individual customers. For two, the focus is business to business; that is having companies and organizations rather than individual consumers as the primary customer. The business focus for the rest of our respondents is mixed. All of the companies in the sample have substantial workforces. Ten have been in operation for over a century. 
Table 1: Characteristics of Participating Corporations

\begin{tabular}{|c|c|c|c|c|c|c|}
\hline & Sector & Scope & Subsidiary & Main Focus & Employees & Longevity yrs. \\
\hline 1 & Media & Regional & Yes & $\mathrm{B}$ to $\mathrm{C}$ & 6880 & $>100$ \\
\hline 2 & Media & National & Yes & $\mathrm{B}$ to $\mathrm{C}$ & 5000 & $>100$ \\
\hline 3 & Finance & Global & No & $\mathrm{B}$ to $\mathrm{C}, \mathrm{B}$ to $\mathrm{B}$ & 37000 & $>100$ \\
\hline 4 & Finance & Global & No & $\mathrm{B}$ to $\mathrm{C}, \mathrm{B}$ to $\mathrm{B}$ & 60000 & $>100$ \\
\hline 5 & Finance & Global & No & $\mathrm{B}$ to $\mathrm{B}$ & 20000 & $>100$ \\
\hline 6 & Retail & National & Yes & $\mathrm{B}$ to $\mathrm{C}$ & 39000 & $>50$ \\
\hline 7 & Retail & National & No & $\mathrm{B}$ to $\mathrm{C}$ & 70000 & $>400$ \\
\hline 8 & Technology & Global & No & $\mathrm{B}$ to $\mathrm{B}$ & 10000 & $>100$ \\
\hline 9 & Technology & National & No & $\mathrm{B}$ to $\mathrm{C}, \mathrm{B}$ to $\mathrm{B}$ & 20000 & $>35$ \\
\hline 10 & Technology & Global & Yes & $\mathrm{B}$ to $\mathrm{B}, \mathrm{B}$ to $\mathrm{C}$ & 300000 & $>80$ \\
\hline 11 & Natural Resources & Global & No & $\mathrm{B}$ to $\mathrm{B}$ & 10000 & $>100$ \\
\hline 12 & Natural Resources & National & No & $\mathrm{B}$ to $\mathrm{C}, \mathrm{B}$ to $\mathrm{B}$ & 4800 & $>30$ \\
\hline 13 & Food/Beverage & Global & Yes & $\mathrm{B}$ to $\mathrm{C}, \mathrm{B}$ to $\mathrm{B}$ & 23000 & $>100$ \\
\hline 14 & Food/Beverage & Global & Yes & $\mathrm{B}$ to $\mathrm{C}, \mathrm{B}$ to $\mathrm{B}$ & 3000 & $>200$ \\
\hline
\end{tabular}

\section{Results}

\section{Usefulness of Austin's (2002) and Zadek's (2004) frameworks}

This study consolidated the models proposed by Austin (2000) and Zadek (2004) to use as the framework for analysing the 14 case studies of Canadian corporations. Austin's philanthropic stage of the continuum is similar to Zadek's defensive, which we call Type 1. Austin's transactional, which we call Type II, encompasses Zadek's compliant, managerial and strategic stages. We renamed the last stage as commercial, to differentiate it from strategic philanthropy. The final stage, Type III, includes Austin's integrative and Zadek's civil stages. The organizational practices, attitudes and features described for each of these types emerged as themes through our analysis of the interview transcripts. Whereas Austin's and Zadek's models detail the value placed on CSR activities at various stages of organizational learning and as companies progress along a collaboration continuum, our analysis reveals differences in organizational policies, procedures and company culture for each of the types identified. Table 2 presents the theoretical framework that emerged from our analysis, listing the companies that displayed the various features. As the interviews were open-ended, not all scored in each category.

\section{Type I: The defensive company: insulated from community}

As Zadek (2004) notes, the defensive company faces often unexpected criticism from community members regarding its approach to social responsibility. A Type I company engages in philanthropy only under duress, most notably when there is an immediate and direct threat to the company's reputation and/or profit. As a result, philanthropic investments are reactive in nature and are not planned - as such, the funds are treated as one-time expenses designed to "weather a storm" of criticism. These quick philanthropy decisions are made by the CEO, or some other senior executive in an atmosphere of heavy public scrutiny and media attention. Although some resources will be allocated to nonprofit organizations, other funds may be directed to image and public relations consulting. The defensive corporation envisions itself as separate from the community even though its employees may be members of the community. As a result, relationships with the community are either non existent or antagonistic. 
Table 2: Case Study Results in a Typology of Corporate Philanthropy in Selected Canadian Companies

\begin{tabular}{|c|c|c|c|c|c|}
\hline \multirow{3}{*}{ Features } & \multicolumn{5}{|c|}{ Nature of Corporation } \\
\hline & \multirow{2}{*}{$\begin{array}{c}\text { Type I } \\
\text { Defensive }\end{array}$} & \multicolumn{3}{|c|}{ Type II } & \multirow{2}{*}{$\begin{array}{c}\text { Type III } \\
\text { Civic }\end{array}$} \\
\hline & & Compliant & Managerial & Commercial & \\
\hline \multirow{2}{*}{$\begin{array}{l}\text { Motivation for } \\
\text { philanthropy }\end{array}$} & $\begin{array}{c}\text { To react to } \\
\text { threat }\end{array}$ & $\begin{array}{l}\text { To secure license } \\
\text { to operate }\end{array}$ & To create goodwill & $\begin{array}{c}\text { To provide } \\
\text { marketing support }\end{array}$ & $\begin{array}{l}\text { To improve } \\
\text { society }\end{array}$ \\
\hline & & Nat 11 & $\begin{array}{l}\text { Media } 1 \\
\text { F/B } 13\end{array}$ & $\begin{array}{ll}\text { Ret } 6, & \text { Tech } 8,9 \\
\text { Nat } 12 & \end{array}$ & $\begin{array}{l}\text { Media } 2 \\
\text { Fin 3,4 }\end{array}$ \\
\hline \multirow{2}{*}{$\begin{array}{l}\text { Objective of } \\
\text { philanthropy }\end{array}$} & Damage control & "Pet projects" & $\begin{array}{l}\text { Corporate } \\
\text { donations }\end{array}$ & $\begin{array}{c}\text { Public Relations } \\
\text { CRM }\end{array}$ & $\begin{array}{c}\text { Development of } \\
\text { society }\end{array}$ \\
\hline & & Tech 9 & $\begin{array}{ll}\text { Media } 1 & \text { Fin 5 } \\
\text { Nat 11 } & \text { F/B 13, } 14 \\
\end{array}$ & $\begin{array}{l}\text { Ret } 7 \\
\text { Nat } 12 \\
\end{array}$ & $\begin{array}{l}\text { Media } 2 \\
\text { Fin 3,4 }\end{array}$ \\
\hline \multirow{2}{*}{$\begin{array}{l}\text { Project } \\
\text { timeframe }\end{array}$} & $\begin{array}{l}\text { Immediate } \\
\text { future }\end{array}$ & Short-term & Mid-term & Long-term & $\begin{array}{c}\text { Multi- } \\
\text { generational }\end{array}$ \\
\hline & & Ret 6 & F/B 13, 14 & $\begin{array}{ll}\text { Media 1 } & \text { Ret } 7 \\
\text { Tech } 9 & \\
\end{array}$ & $\begin{array}{l}\text { Media } 2 \\
\text { Fin 3,4 }\end{array}$ \\
\hline \multirow{2}{*}{$\begin{array}{l}\text { Application } \\
\text { process } \\
\text { for NPOs }\end{array}$} & None & Informal & Formal & Planned & Integrated \\
\hline & & $\begin{array}{ll}\text { Media 1 } & \text { Ret 6 } \\
\text { Tech 9 } & \text { F/B 14 } \\
\end{array}$ & $\begin{array}{l}\text { Tech } 8,10 \\
\text { Nat } 11\end{array}$ & $\begin{array}{ll}\text { Fin 3,5 } & \text { Ret 7 } \\
\text { Nat 12 } & \text { F/B 13 } \\
\end{array}$ & Media 2 \\
\hline \multirow{2}{*}{$\begin{array}{l}\text { Type of } \\
\text { relationship with } \\
\text { NPOs }\end{array}$} & None & Donor & Funder & Sponsor & Partner \\
\hline & & Ret 6 & Tech 8 & $\begin{array}{l}\text { Ret } 7 \text { Tech 8,9,10 } \\
\text { F/B } 13\end{array}$ & $\begin{array}{l}\text { Media } 2 \\
\text { Fin 3,4 }\end{array}$ \\
\hline \multirow[t]{2}{*}{$\begin{array}{l}\text { Decision } \\
\text { makers }\end{array}$} & None designated & Senior executives & $\begin{array}{c}\text { Community affairs } \\
\text { department }\end{array}$ & Strategic planners & $\begin{array}{l}\text { Full community } \\
\text { of stakeholders }\end{array}$ \\
\hline & & $\begin{array}{l}\text { Tech } 9 \\
\text { F/B } 14 \\
\end{array}$ & $\begin{array}{ll}\text { Ret 6 } & \text { Tech } 8 \\
\text { Nat 11 } & \\
\end{array}$ & $\begin{array}{l}\text { Tech 10 Nat } 12 \\
\text { F/B 13 }\end{array}$ & Fin 3 \\
\hline \multirow{2}{*}{$\begin{array}{l}\text { Role in corporate } \\
\text { philanthropy field } \\
\text { (include capacity- } \\
\text { building effort } \\
\text { with NPOs) }\end{array}$} & No role & Casual & Observer & Key participant & Innovator \\
\hline & & & $\begin{array}{ll}\text { Media 1 } & \text { Tech 8 } \\
\text { Nat 11 } & \text { F/B 13 }\end{array}$ & $\begin{array}{ll}\text { Fin 5 } & \text { Ret 7 } \\
\text { Tech 8,10 } & \text { Nat 12 } \\
\text { F/B 14 } & \\
\end{array}$ & $\begin{array}{l}\text { Media } 2 \\
\text { Fin } 3,4\end{array}$ \\
\hline \multirow{2}{*}{$\begin{array}{l}\text { Employee } \\
\text { involvement }\end{array}$} & None & External & Diffuse & Collaborative & Fluid \\
\hline & & $\begin{array}{ll}\text { Media 1 } & \text { Ret 6 } \\
\text { Tech 9 } & \text { Nat 11 }\end{array}$ & $\begin{array}{ll}\text { Tech } 8 & \text { Nat } 12 \\
\text { F/B13 } & \end{array}$ & $\begin{array}{ll}\text { Fin 3,4,5 } & \text { Ret 7 } \\
\text { Tech 10 } & \text { F/B 14 }\end{array}$ & \\
\hline \multirow{2}{*}{$\begin{array}{l}\text { Company culture } \\
\text { in relation to } \\
\text { philanthropy }\end{array}$} & Closed & Haphazard & Diffuse & Streamlined & Integrated \\
\hline & & $\begin{array}{ll}\text { Ret } 6 & \text { Tech } 9 \\
\text { Nat } 11 & \\
\end{array}$ & $\begin{array}{l}\text { Fin } 5 \text { Tech 8,10 } \\
\text { Man } 13\end{array}$ & $\begin{array}{l}\text { Fin } 3,4 \\
\text { Ret } 7 \\
\end{array}$ & Media 2 \\
\hline Media (Media): & \multicolumn{5}{|c|}{$\begin{array}{l}\text { 1. Media } 1 \text { - straddles compliant and managerial categories (weak Type II) } \\
\text { 2. The Media } 2 \text { - civil (Type III) }\end{array}$} \\
\hline Finance (Fin): & $\begin{array}{l}\text { 3. Finance } \\
\text { 4. Finance } \\
\text { 5. Finance }\end{array}$ & $\begin{array}{l}-\operatorname{civil}(\text { Type III) } \\
-\operatorname{civil} \text { (Type III) } \\
- \text { commercial (strong T }\end{array}$ & 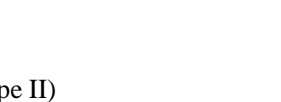 & & \\
\hline Retail (Ret): & \multicolumn{4}{|c|}{ 6. Retail 6 - compliant (weak Type II) } & \\
\hline Technology (Tech): & \multicolumn{4}{|c|}{$\begin{array}{l}\text { 9. Technology } 9 \text { - hybrid Type II - straddles all three categories } \\
\text { 10. Technology } 10 \text { - hybrid but strong Type II - straddles managerial and commercial }\end{array}$} & \\
\hline Natural Resources (Nat) & \multicolumn{4}{|c|}{$\begin{array}{l}\text { 11. Natural Resources } 11 \text { - managerial (middle Type II) } \\
\text { 12. Natural Resources } 12 \text { - commercial (strong Type II) }\end{array}$} & \\
\hline Food/Beverage (F/B): & \multicolumn{4}{|c|}{$\begin{array}{l}\text { 13. Food/Beverage } 13 \text { - hybrid but strong Type II - straddles managerial and commercial } \\
\text { 14. Food/Beverage } 14 \text { - hybrid Type II - straddles all three categories }\end{array}$} & \\
\hline
\end{tabular}


Among our fourteen case studies, none was in the Type I defensive category either because we did not ask any such companies to participate or we asked and they refused. This represents one of the limitations of this study. One possible scenario is that Type I companies declined interviews because they were unwilling to discuss their nonexistent (or sometimes even antagonistic) relationship with the community in which they operate, underlining the closed, or insulated, corporate culture of the defensive corporation. Another explanation for the paucity of corporations that fit the defensive profile is that corporate philanthropy has become an industry standard. Corporations "are almost penalized if [they] are not doing CSR" (Finance 5). This suggests that the values in the corporate sector as a whole are evolving and there is now a bar for social responsibility, just as there is a bar for accountability and transparency.

\section{Type II: Transitional philanthropy: negotiating corporate and community roles}

As noted above, the past decade has ushered in significant changes in the political and economic context for relationships between the nonprofit and profit sectors in Canada. While nonprofit agencies are seeking additional financial partners in a time of unstable government funding, corporations are also building innovative solutions to societal programs by leveraging their considerable resources. As such, this is a particularly fruitful time for cross sector collaboration, characterized by a variety of approaches. The Type II company reflects these changing times; and thus there are three subtypes: a) compliant; b) managerial; and c) commercial. Few companies fit neatly and "perfectly" into any particular subtype. More often, these transitional companies straddle characteristics of several subtypes, pointing to the fluid, rapidly changing, and dynamic nature of corporate philanthropy positions. In fact, at least six of our interviewees indicated that their policies and procedures had recently undergone, or were slated to undergo, significant overhaul. Nevertheless, it is possible to describe general tendencies and the current "standing" position of most of the focal companies.

Compliant. The compliant company does not formally involve employees or others in its decision-making process about fund allocation. Funds are purely discretionary, and funds are generally allocated according to executives' personal and or social goals. Exclusive prestige networks are the major resources used to build philanthropy for the compliant company. Since this knowledge is nontransferable, philanthropic management capacity is not built within the company. Since support is usually monetary, there is little knowledge sharing between nonprofits and the corporation. The relationship revolves around the exchange of dollars for a modicum of legitimacy.

One example of a mostly compliant company is Retail 6. While it considers its philanthropy sufficient, it is doing much less than other companies we interviewed. It considers doing a small but recognizable amount of philanthropy as a necessary cost of doing business. In this sense, community giving secures a "non-regulatory license to operate" (Zadek, 2004) in the community. This type of giving is often called "cheque-book philanthropy" as the company has no involvement in the community past the public cheque presentation or ribbon-cutting ceremony. Since the communities that receive philanthropy are primarily overseas, this lack of involvement most likely goes unnoticed by Retail 6's customer base in Canada. Unlike most other companies in our sample whose philanthropic approach has undergone significant revision in the past five years, Retail 6 notes that it hasn't changed its approach for 10 years because it feels its current strategy is working well.

Managerial. As defined by Zadek (2004), the managerial company is not seeking innovative solutions per se, but is trying to better manage the pressing present. It recognizes the importance of its stakeholders' opinions on community involvement; these stakeholders of course include traditional shareholders and senior executives, but also civic and community leaders, company employees and other community members. The relationship in this case is once again focused on the exchange of money for a broader level of institutional legitimacy. 
A company like Natural Resources 11 takes a "community approach" to philanthropy because it tends to have its operations based in northern and rural communities. "When you move into a place, you help build the community because you need to...if you want to keep your employees in the community". Building community for resource companies means becoming involved in developing and supporting education, health and social services. Their motivation for this involvement includes both concern for the larger community, and solving human resources challenges. "As corporate citizens we knew we had to build hospitals and build schools....otherwise we wouldn't have people wanting to work for us."

As such, Natural Resources 11 has a formal administrative structure in place to handle its relationships with community organizations. Nonprofit organizations are selected for funding approval based on their geographical proximity to the company's operations or based on their emotional proximity to the company's employees. Despite Natural Resources 11's intentions to be a "good neighbour", its strategy results in procedures that are more reactive in nature, offering solutions to existing problems and incoming requests, rather than a proactive approach to managing philanthropy. The company admits it does not have the internal capacity to be effective in outreach for new and innovative relationships with the nonprofit sector.

Commercial. One of the indicators for a managerial corporation's moving along Zadek's learning curve toward the commercial category, is when it begins to consider integrating its donation strategy with some of its marketing and business objectives. "Everyone has an interest in participating charitably. [...] And that without some kind of centralized direction, this can look very chaotic. And so it was really through ourselves and the franchise community that we decided to choose a charitable direction where we could benefit the people who supply the product that ultimately makes us successful." (Retail 7) The relationship with non-profits for the commercial companies is not so much about giving dollars in exchange for community legitimacy, as it is about exchanging their resources for community recognition and public relations - recognition that can ultimately translate into commercial benefits.

Retail 7 is another Type II company that makes its employees, or associates, a key part of its philanthropic approach. Its charitable activities focus on "visibility and making a difference....[It] really believes that if [it] builds a program of some sort to empower [its] associates to define who we are as Canadians in the community to give back, that would make a bigger impact...and through making that impact, our associates would be feeling proud about what they do". This is related of course, to the retailer's significant historical role in shaping Canada as a nation. The company directly asks for employee input to determine the focus of its philanthropy and actively raises money for those causes through retailer-based initiatives. For example, Retail 7 has developed a relationship with women's shelters in Ottawa based on employee involvement in those shelters. The employees provide translation, fundraising, space, and technological support to these shelters because the small agencies "don't have time to organize fundraising". However integral employee involvement is to Retail 7, there is a business rationale to this approach. "We've all been hearing more and more about CSR, about transparencies, about companies being transparent in their business operations. I think we [as a company] started probably just before all of that really started coming to life. But overall what we are trying to do is more than just be a good corporate citizen, [we want] to help drive the business....It's one thing to be socially responsible, but how do you help give back to the bottom line rather than just always giving out." As a result, some of their philanthropic activities have multiple objectives: "to give back to the community...to motivate our associates, to help educate our customers about [our company]."

Food/Beverage 13, another Type II corporation traces its social conscience back to the founder who "believed that every business should give back to the community." For example, when it closed a plant in a community, it "pledged to give \$200,000 a year for 10 years" to be used to support charitable causes in that community. Many of Food/Beverage 13's philanthropic activities are initiated at the local level. "We had a community investment program called 'Local Heroes' and that was giving back to small 
grass root communities across Canada to help fix up and revitalize recreational facilities." The company helped with the cost of materials, but it was up to a community leader to "get a team of volunteers together" to do the work.

Other activities include sponsorships, but interestingly, they are not managed through the Corporate Affairs Department as are other philanthropic programs. Nor are they necessarily initiated by the company. For example, as a result of CEO interest, the company has a sponsorship with elite amateur athletes. "He thinks it is good for the corporation to support amateur athletics... and he took that forward to our board of directors."

Food/Beverage 13 has a reactive approach to philanthropy as illustrated by its concern about its lack of focus. "We took a look at our donations fund and thought ...we are not making any impact on anything because we are giving $\$ 500$ here and $\$ 1000$ there. We were just really responding; we were being reactive instead of proactive, and just really had no structure about how we were giving." In attempting to come up with a focus, it made the decision internally. "We made the decision; we didn't have anyone from the outside... We've done research to see what....matters to our consumers." This contrasts with the process used by some of the civil companies who sought outside expertise in identifying a focus. As a result of this work on embedding philanthropy into managerial processes, this activity has become more centralized with individual local committees being disbanded. However, the structure for philanthropic activities seems to mirror the overall organizational philosophy. "We've always structured it the same as the company structure....For a few years, the company is centralized, and [then] it goes decentralized. So we react to that."

Natural Resources 12 is a company that felt the pressure to focus and be strategic and is in the process of transitioning its policies and procedures to meet that goal. "We've spent the last couple of years trying to go from the charity and nonprofit setting our agenda to the committee setting a bit of its own agenda. Rather than just being a committee that reviews piles of proposals, [we want] to be in the position where we sit down as a committee and say "what do we want to be involved in, what makes sense to be involved in, and what do we not want to be involved in".

The commercial company engages in philanthropy in order to create a competitive edge. As such, philanthropic resources are being directed primarily to public relations and cause-related marketing initiatives, with additional funds going towards straight donations. Previously, Natural Resources 12 was largely a "funder". Its major concern was that it was a "good program" and that its "name was spelled right when [it was] put up on the plaque." But now, Natural Resources 12 differentiates its approach into these two streams, sponsorship and donations, and generally develops two sets of funding guidelines for each. Now, its primary role is that of sponsor. As the commercial company's strategic approach to philanthropy is decided by the company's strategic planners, funding allocations are committed within the company's long-term planning framework; this may include both one-time donations and also, in Natural Resources 12's case, "a multi-year commitment" to selected nonprofits that meet strategic sponsorship criteria. All philanthropic goals are aligned to corporate goals and objectives and are reported to the company's board of directors.

Further, Natural Resources 12 has now started to do some capacity building. The commercial company begins to innovate its philanthropy programs the same way it would innovate business solutions, proactively seeking out unique nonprofits that need their help. The commercial company shares its specialized expertise and knowledge with nonprofit agencies. "Groups have come to us with a great idea; they just don't quite have all the pieces together." One such "gem" organization had an idea to "donate used inkjet cartridges to the food bank....called 'think food' and the food bank would get the proceeds". The organization lacked the expertise to develop a compelling promotion strategy or logistical plan. As a result, Natural Resources 12 "sat down and [it] developed a marketing plan.... with some of its human 
resources. [It] helped them launch, showed them how to get a press release on the newswire and how to get media out." Currently, it is the founding sponsor of this program, and has been able to "pull back" because "the training wheels are off and they're running."

Natural Resources 12 reiterates a belief that appears to be common among Canadian corporations that engaging in CSR is no longer a luxury for large well-heeled organizations, but a necessity for all companies. "If you're going to do business in this country in a big way, you need to be part of the overall social fabric.".... "so it is a requirement of doing business, and if anyone hasn't figured that out yet, then they are playing with fire."

\section{Type III: The corporation as community}

The second focus of the research was on gaining a deeper understanding of what differentiates Type III companies from the rest. Companies in the civil category accept a collective responsibility to improve society by leveraging their organization's key competencies and resources to develop a philanthropic agenda that contributes to broad, positive, social outcomes. This philosophy reflects Porter's and Kramer's (2002) view of the objective of strategic philanthropy and goes far beyond the public relations activities and cause-related marketing that are sometimes labelled as strategic. In this case the relationship between the corporation and the non-profit sector is focused on building multiplexed partnerships to address widely recognized social problems - problems beyond the scope of any one sector to solve. For example, proactively, Media 1 approached city libraries and together they developed a program to help new immigrants access information. This $\$ 2.5$ million program has a 20 -year commitment. "Using this prototype, we were able to convince the [allocations] committee that this is the kind of grant that is needed, whatever the term was....in order to have an impact, a real true impact." "What it did was it helped establish the library as a resource centre in the minds of a lot of people who may not have even known or were intimidated by going into a research library or reference library to use it for more than a job hunt." As exemplified by this program, Media 1 suggests that corporations "have a huge responsibility to give back to a community that supports them....not just providing funding, but maybe expertise".

Another feature of Type III corporations is that they conceptualize and fund projects with either multi-generational timelines (e.g. 20 years) or no specific end date, because they believe that making a difference in society takes time and social outcomes cannot easily be quantified or measured. Both Media 1 and Finance 3 fund multi-generational projects whose benefits cannot be easily quantified. Their community project for youth at risk has benefits that reach into the future. Finance 3 jokingly says that it won't know the success of its scholarship program "until the year 2050 when one of these kids wins the Nobel Prize or becomes Prime Minister or both". This is particularly noteworthy, as much of the academic literature has focused on measuring social outcomes and documenting progression toward long term social goals. In contrast, corporations actually engaging in CSR recognize the difficulty of demanding this level of accountability and do not make it a priority. Likewise, they do not limit themselves to causes with outcomes that can be easily measured and quantified within a specific period of time.

In choosing their "causes" and operationalizing their plans, these companies consult outside experts and even members of the target audience to ensure that they will focus on areas with the greatest need and allocate their funds wisely. Nonprofit partners may even be integrated into the management structure and the board of directors. Finance 3 conducted research and consulted its community of stakeholders and other experts before determining its strategic focus. "We went to a variety of institutions including [a particular university], and spoke with some of the [other] universities. We actually endow a chair at [ a specific university] around the subject of youth unemployment, so we talked to some of the people who were doing root cause analysis. [We] talked to people in the [nonprofit umbrella 
organization]....From that we determined that mentoring seemed to be important ..... and what age groups were particularly useful to address." In this way, Finance 3's chosen direction was the result of collaboration: "It wasn't' something that somebody came up with here [at Finance 3] on the back of an envelope...I think we are more comfortable with that fact because we really did spend the time and we weren't pushing somebody's pet project from the inside". These interactions with the community are less about being seen to do the right thing, and more about identifying and executing the right thing.

In contrast, Finance 5, a Type II company, whose business focus is primarily life insurance with some financial services, is not at the same level for proactive partnership as Finance 3 and Finance 4. Because of an overwhelming number of requests for support, they are working to streamline their focus in the future and actively seek meaningful partners instead of waiting for requests to flood in and then sort through them. Finance 5 suggests that this is a trend for the future: "We haven't really had the opportunity to develop our own program, then go out to a charity and say let's partner on this, and that is unfortunate, and I think that is something we want to do, and I think a lot of companies are going that way.... and we might be able to see the start of a change."

Civil companies like Finance 3 and Finance 4 see philanthropic activities as key to their identity; Finance 3 notes that they "would like to be seen as a leader" (Berger, Cunningham, \& Drumwright, 2006). Both Finance 3 and Finance 4 are not only members of corporate philanthropy associations, but also they are key innovators in the field. One interviewee in another sector highlighted the fact that Finance 3 organizes an event "that is now probably the most successful mass participation event which raises money for [a cause], mobilizes the community, gets people out on a Sunday morning, and makes huge numbers of people think about the subject.... Lots of people would like to be able to replicate that for their own organization" (Media 2 commenting on Finance 3). Their approach to community is often imitated by others. For example, Finance 4 has a formal system for allocating funds that requires audited financials and may entail a site visit. This type of rigorous oversight is viewed as "due diligence" on behalf of one of Canada's most generous philanthropic supporters. So well known is Finance 4 for its evaluation and research that other companies support the same causes without engaging in their own due diligence. If the organization has been able to secure funding from Finance 4, then it is assumed that it would pass any requirements set up by other companies. This is an example of the power of some sponsors to give nonprofit organizations credibility in the eyes of other sponsors, a key feature of a company that truly exemplifies strategic philanthropy according to Porter and Kramer (2002).

Although operating in the same sector and market, Media 1 and Media 2 had highly divergent corporate philanthropy strategies and backgrounds. At Media 2, a company that straddles compliant and managerial subtypes of Type II, corporate philanthropy is discussed not so much in terms of what the company is doing, but rather from the perspective of the organizations with which senior management is involved and their particular interests and projects. Indeed, the actual decision about what to support "ultimately finally arrives at [the publisher's] desk and [he] signs off on it or not." Its philanthropy strategy is not as well developed as that of Media 1. In addition to rather ad hoc procedures for determining whether to support particular charitable causes and organizations, Media 2 also has an "ad hoc system of making a judgment" about whether the project has been "well-executed and welldelivered" and will "pull out of those things where [it] feels the management of a particular cause is not doing a good job." There is concern that any involvement in charitable ventures "reflect well" on the Media 2.

The attitudes toward philanthropic activities are quite different at Media 1, a Type III company. In this organization, philanthropy is "actually a core of the business", and "part of the culture". Achieving this position has been facilitated by a past leader whose personal philosophy set up the governing principles and priorities of the organization. A significant publisher in Media 1's past refocused the organization to be one that is "for the people". He wanted his company "to look out for the 
little guy". This tradition continues today, and has "simply grown with the times". It has two foundations, viewed as "the soul of [the] company", that provide Christmas packages to needy families and send twenty to twenty-five thousand children to summer camp. This way of doing business is taken for granted by socially-minded employees because it is the way things have always been done. Stories and myths reflecting these values are commonly shared by employees and play a significant role in its history and traditions. These separate foundations were created to address the issues and problems abandoned by both governments and the private sector. The foundations were envisaged as a stopgap measure until the government could be lobbied and persuaded to address these social gaps. Almost 100 years later, these foundations still exist and are part of the social safety net in Toronto.

\section{Discussion and Conclusion}

As indicated earlier, Table 2 presents the results of our interviews in the context of our consolidated Austin/Zadek model. What we learned from those interviews is that there are very few "pure" types. As Austin (2002) points out, many companies are hybrids and as commitment to corporate philanthropy evolves, there is not necessarily a progression from one end of the continuum to another. There were three companies that seemed to exemplify all the characteristics of Austin's integrative (2000) and Zadek's civil classification (2004), and what we have called Type III. The rest can best be characterized as what Austin calls transactional and what we have called Type II. One resource company was a "pure" managerial; another was "pure" commercial. One of the retailers was at the compliant end of Type II, whereas the other was at the commercial end. Most of the rest had characteristics of all three categories of Type II. In terms of sector differences, there appear to be no consistent trends that can be identified. However, two of the three financial companies are in the Type III civil category and one is at the commercial end of Type II, suggesting a relationship between either type of business or size of profits and commitment to CSR.

In terms of consistency with the results from US studies, we learned that contrary to Saiia et al.'s (2003) and Smith's (1994) findings that companies engaging in strategic philanthropy evaluate outcomes with the same rigour as business activities, we found no such evidence in our Canadian sample, even among companies who were Type III. From the comments of our respondents about their motivation for choosing particular activities and the value of CSR, it appears that there is support for Porter's and Kramer's (2002) assertion that much of what is termed strategic philanthropy is actually public relations or cause-related marketing. Our respondents point out the need for "business rationale", "alignment", "brand recognition" and "reputation" as reasons for supporting and encouraging philanthropic activities. This is particularly significant for commercial companies. It is only the three companies in the civil category that mention broader societal goals, or do research on identifying where is the greatest need, as opposed to choosing only those causes that will have the greatest business impact.

We also gained insight into what differentiates Type II companies from Type III organizations. Type II companies describe their motivation for involvement in CSR as a response to external pressure. Several mention the link between social responsibility and corporate success. There are multiple sources for this pressure including an increase in requests from nonprofits, government expectations of corporate contribution to society, and employee, customer and shareholder expectations about corporate citizenship. Type III companies use different language. They do not report feeling external pressure for engaging in socially responsible activities. Instead they have integrated a commitment to CSR into their corporate culture, processes and practices and as a result their companies are role models for others. They try to influence others to become involved through example or by identifying worthwhile causes through their own due diligence. 
Type II companies are by definition in transition. One of the motivations for them to re-examine the nature and scope of their involvement in CSR is dissatisfaction with current policies, practices and outcomes. At least five of our Type II companies are in the process of re-examining how they support social causes. The common themes, in terms of the direction of the changes, were to be more targeted with their social and cause involvements, to be able to make a real difference and to have an alignment with their business objectives, so that there would be some business benefit to their activities whether it be employee retention, customer satisfaction, or company reputation. Type III companies, in contrast, choose causes that are not directly linked with their goods or services, rather they address broad social issues, such as poverty, breast cancer and immigration that have far-reaching implications for the social and economic health of Canadian society as a whole. This approach motivates the Type III companies to consult broadly among a wide community of stakeholders and experts, whereas Type II companies do most of their consultation in-house about causes to support with an emphasis on their own market needs. Type II companies talk about their relationships with the nonprofit sector in terms of external alliances and partners. In contrast, Type III companies do not distinguish between those inside their company and those outside the company in terms of working for a particular cause; all are members of the same team.

Given the small number of companies in the Type III category, it may be useful to think of them as innovators. The innovator companies accept their responsibility for leadership in CSR and in some cases this is as a result of having a significant historical leader or founder with a strong social conscience whose values and beliefs defined a corporate culture that has persisted over time. Several respondents mention these companies by name and point out their exceptional fund-raising expertise and achievements, their detailed due diligence, or the attractiveness of co-sponsoring a particular cause if one of these companies is already a sponsor. As Porter and Kramer (2002) point out, a company that is truly strategic in its philanthropic activities can influence others to support particular causes as a result of its own reputation.

This raises the question of the barriers to Type II companies adopting the same mindset. E.M Rogers' (1995) seminal work on diffusion of innovation offers some insight into this issue. He suggested that there were five characteristics of innovations that helped to explain their different rate of adoption by individuals. His framework may apply to organizations and may enhance our understanding of why there are not more companies in the Type III category.

The first characteristic is relative advantage. In order to adopt an innovation, an organization has to perceive that there is a relative advantage in terms of economics, social prestige, convenience and satisfaction. The greater is the perceived advantage; the greater is the rate of adoption. As has been documented above, most companies agree that engagement in CSR is associated with reputational benefits that may or may not translate into economic advantages. The inability to directly link these reputational advantages to market advantages may pose a significant barrier to broad diffusion.

The second characteristic in Roger's framework is compatibility; that is the degree to which the innovation is seen as consistent with existing values, managerial practices, past experiences and the needs of the company. For some companies, this is perceived as a barrier, as CSR is often an add-on activity which is not integrated into mainstream needs of the company. It is separate from the company's "real" business. In addition, there is the perception that being a CSR leader demands a substantial budget investment and only a few companies have the consistent profit levels that allow the development of an infrastructure to support CSR. Furthermore, managing and contributing to broad societal issues demands long time lines, fluid processes and flexible structures, characteristics rarely found in large corporations (Berger, Cunningham, \& Drumwright, 2004). Thus, both financial threshold and company culture may represent significant compatibility barriers to Type III diffusion. 
The third feature is complexity, which refers to the degree to which the innovation is perceived as difficult to understand and use. This may also be a barrier for some Type II companies making the transition to Type III. There is no question that social problems are complex, difficult to solve in the short term, demanding customized investments in infrastructure and complex types of co-operation across societal sectors. Many companies reported being overwhelmed with requests and experiencing difficulty developing a CSR strategy that was compatible with resource levels and strategic goals.

The fourth feature is trialability, that is, the degree to which an innovation may be experimented on a limited basis. This is a concern to many of the Type II companies, as they do not want to "pull the plug" on nonprofit organizations after a year of support, if it is found they do not fit with the company's goals. Thus, there is careful consideration of the causes to which they become associated and a tendency to choose those that are already supported by some of the Type III companies (because the due diligence has been done), or pet projects of senior management (because continuing support may be a priority).

The final feature is observability which means the degree to which the results of the innovation are visible to others. As was documented earlier, the Type III companies have certainly achieved this, as their efforts are the envy of other companies. However, Type II companies often perceive that they do not have the financial resources to create the same level of awareness for their causes as Type III companies are able to achieve.

The internal barriers discussed above are mostly attitudinal, and are supported and reinforced by other internal and external factors. First, all of our Type III companies were rooted in the community or communities in which they operated. This gave them a high level of awareness and in some instances a ready distribution network for building support for the cause. Some of our Type II companies do not have such a well-developed network either on a national or regional basis. Because of Type III's existing networks, they tend to become involved in causes that resonate with all their markets and not just a local issue. The Type II companies tend to have more involvement with strictly local causes, which means national awareness is difficult to achieve.

Another barrier to the adoption of a Type III mentality is the historical relationship of the government to the for-profit and nonprofit sectors in Canada. Until very recently, the government was expected to have almost sole responsibility for the social safety net. It is only in the last decade that corporations have felt pressure from a variety of stakeholders to increase their role in socially responsible activities. This sceptical perception among Canadians about corporations' true motivations may also limit corporate adoption of charitable ventures because of fears of customer backlash.

In this paper we used selected case studies to develop and understand the variety of ways that corporate social responsibility is manifested in Canada. Clearly, Canada, like other locales would greatly benefit from higher levels of commitment to CSR by a larger proportion of Canada's corporate sector. However, promoting and achieving higher levels of engagement is not an easy task. We saw from our study that most companies do engage at some level, but only a select few practice true strategic philanthropy or can be considered truly "civil" organizations. Understanding the characteristics of these innovators, and the factors that differentiate them from less engaged companies can go a long way toward identifying broader strategies for addressing seemingly intractable problems such as poverty, immigrant acculturation or disease and thereby achieving a more civil society. By recognizing the constellation of characteristics that distinguish different types of CSR engagement, companies, nonprofits and governments could design better strategies for developing relationships and partnerships that motivate higher levels of CSR involvement. Furthermore, by understanding SCR growth as an innovation-diffusion process, organizations in all three sectors would be better equipped to identify, mitigate and scale the barriers to achieve broader diffusion. 


\section{References}

Austin, J. E. (2000). Strategic collaboration between nonprofits and businesses. Nonprofit and Voluntary Sector Quarterly, 29 (1), 69-97.

Azer, A. (January, 2003). The changing corporate landscape and its effect on charitable giving. Canadian Centre for Social Entrepreneurship, University of Alberta, School of Business, Edmonton, AB.

Barone, M.J., Miyazaki, A.D., \& Taylor, K.A. (2000). The influence of cause-related marketing on consumer choice: Does one good turn deserve another? Academy of Marketing Science, 28 (2), 248-262.

Berger, I. E., Cunningham, P. M., \& Drumwright, M.E. (2006) Identity, identification and relationship through social alliances", Journal of the Academy of Marketing Sciences, (in press).

Berger, I., Cunningham, P. M., \& Drumwright, M.E. (2004). Social alliances: Company/ Nonprofit collaboration. California Management Review, 47 (1), 58-90.

Burson-Marsteller. (2000). International opinion leader survey on corporate social responsibility. Prince of Wales Business Leaders Forum, U.K.

Canadian Democracy and Corporate Accountability Commission. (2002). The new balance sheet: Corporate profits and responsibilities in the $21^{\text {st }}$ century. Final Report.

Carroll, A.B. (1999). Corporate social responsibility: Evolution of a definitional concept. Business \& Society, 38 (3), 268-295.

Dean, D.H. (2003/2004). Consumer perception of corporate donations: Effects of company reputation for social responsibility and type of donation. Journal of Advertising, 32 (4), 91-102.

Drumwright, M. (1996). Company advertising with a social dimension: The role of noneconomic criteria. Journal of Marketing, 60 (10), 71-87.

Fiske Gwin, C. (2000). The perspective of nonprofit marketing organizations on cause-related marketing. American Marketing Association. Conference Proceedings, 11, 348-349.

Foster, M.K. \& Meinhard, A.G. (2005). The diversity of revenue sources among voluntary organizations in Canada. Nonprofit Management and Leadership 15 (3), 43-60.

Foster, M.K. \& Meinhard, A.G. (November, 2002). CSR in the Canadian context: The new role of corporations in community involvement and social issues. Presented at the annual ARNOVA Conference, Montreal, Quebec.

Graves, F.L. (1999). Rethinking government as if people mattered: From Reagonomics to humanomics. In L.A. Pal (ed.) How Canada spends 1999-2000: Shape shifting: Canadian governance toward the $21^{\text {st }}$ century, (pp.37-73). Oxford University Press Canada.

Hall, M. \& Banting, K.G. (2000). The nonprofit sector in Canada: An introduction. In K.G. Banting (Ed.), The nonprofit sector in Canada: Roles and relationships (pp. 1-28). Montreal and Kingston: School of Policy Studies, Queen's University. 
Hemphill, T.A. (2004). Corporate citizenship: The case for a new corporate governance model. Business and Society Review, 109 (3), 339-361.

Imagine Canada. (2002). Statistics on corporate giving in Canada. Available at www.imagine.ca/content/resources.

Jeffrey, B. (1999). Hard Right Turn: The New Face of Neo-Conservatism in Canada. Toronto: HarperCollins Publishers, Inc.

Johnson, A.F., McBride, S. \& Smith, P.J. (1994). Introduction. In Johnson, A.F., McBride, S. and Smith, P.J. (Eds.) Continuities and Discontinuities: The Political Economy of Social Welfare and Labour Market Policy in Canada. Toronto: University of Toronto Press.

Kosminsky, J. (1997). Venture philanthropy: A new model for corporate giving. Fund Raising Management, 28 (6), 28-31.

Levin, A.E. (1982). Updating social responsibility. Canadian Banker and ICB Review, 89 (5), 56-61. Marx,

J.D. (1999). Corporate philanthropy: What is the strategy? Nonprofit and Voluntary Sector Quarterly, 28 (2), 185-198.

McAlister, D.T. \& Ferrell, L. (2002). The role of strategic philanthropy in marketing strategy. European Journal of Marketing, 36 (5/6), 689-743.

McBride, S. \& Shields, J. (1997). Dismantling a Nation: The Transition to Corporate Rule in Canada. Halifax: Fernwood Publishing.

Murphy, B. (1995). Volunteerism: Another kind of giving. Across the Board, 32 (4), 25.

Muttart Foundation. (2002). Charities score high on meeting needs. Available at www.muttart.org.

Pal, L.A. (1997). Civic re-alignment : NGOs and the contemporary welfare state. In R.B. Blake, P.E. Bryden, and J. F. Strain (Eds.), The Welfare State in Canada: Past, Present and Future. Concord: Irwin Publishing.

Phillips, R. (2000). The corporate community builders: Using corporate strategic philanthropy for economic development. Economic Development Review, Summer, 7-11.

Pinney, C. (June, 2001). More than Charity: Building a New Framework for Canadian Private Voluntary Sector Relations. Discussion Paper for Imagine's Voluntary Sector Forum, Canadian Centre for Philanthropy, Toronto.

Porter, M.E. \& Kramer, M.R. (2002). The competitive advantage of corporate philanthropy. Harvard Business Review, 80 (12), 57-68.

Post, J.E. \& Waddock, S.A. (1995). Strategic philanthropy and partnerships for economic progress, philanthropy and economic development. In R.F. America (Ed.), Philanthropy and economic development (pp.167-191). Westport, CT: Greenwood. 
Prince, M.J. (1999). From health and welfare to stealth and farewell: Federal social policy 1980-2000. In L.A. Pal (ed.) How Canada spends 1999-2000: Shape shifting: Canadian governance toward the $21^{\text {st }}$ century, (pp. 151-196). Don Mills, ON: Oxford University Press Canada.

Rogers, E.M. (1995). Diffusion of innovations, $4^{\text {th }}$ edition. New York: The Free Press.

Saiia, D.H, Carroll, A.B., \& Buchholtz, A.K. (2003). Philanthropy as strategy. Business \& Society, 42 (2), 169-201.

Salamon, L.M. (1987). Partners in service. In W.W. Powell (Ed.). The Nonprofit Sector: A Research Handbook (pp. 107-117), New Haven: Yale University Press.

Salamon, L.M. (1995). Partners in Public Service: Government-Nonprofit Relations in the Modern Welfare State. Baltimore: Johns Hopkins University Press.

Schmid, H. \& Meinhard, A. (November, 2000). A Comparative Analysis of Emerging Partnerships between Corporations and Nonprofit Social Service Organizations in Canada and Israel. Presented at the annual ARNOVA Conference, New Orleans, LA.

Smardon, B. 1991. The federal welfare state and the politics of retrenchment in Canada. Journal of Canadian Studies, 26(2), 122-141.

Smith, C. (1994). The new corporate philanthropy. Harvard Business Review, 73 (3), 105-116.

Smith, W. \& Higgins, M. (2000). Cause-related marketing: Ethics and ecstatic. Business and Society, 39 (3), 304-322.

Tucker, D.J., Singh, J.V. \& Meinhard, A.G. (1990). Organizational form, population dynamics and institutional change: A study of birth patterns of voluntary organizations. Academy of Management Journal, 33, 151-178.

Varadarajan, P.R. \& Menon, A. (1988). Cause-related marketing: A coalignment of marketing strategy and corporate philanthropy. Journal of Marketing, 52, 58-74.

Waddock, S.A. \& Graves, S.B. (1997). The corporate social performance-financial performance link. Strategic Management Journal, 18 (4), 303-319.

Webb, D.J. \& Mohr, L.A. (1998). A typology of consumer responses to cause-related marketing: From sceptics to socially concerned. Journal of Public Policy \& Marketing, 17 (2), 226-238.

Yehiam, E., Barron, G., Erev, I., \& Erez, M. (2003). On the robustness and direction of the effect of cause-related marketing. Journal of Consumer Behavior, 2 (4), 320-332.

Zadek, S. (2004). The path to corporate responsibility. Harvard Business Review, 82 (12), 125-132.

Zeghal, D. \& Ahmed, S.A. (1990). Comparison of social responsibility information disclosure used by Canadian firms. Accounting, Auditing and Accountability Journal, 3 (1), 38-53. 